\title{
IMPLEMENTING CORPORATE SOCIAL RESPONSIBILITY: A CREATIVE TENSION BETWEEN REGULATION AND CORPORATE INITIATIVES?
}

\author{
THOMAS CLARKE AND ALICE KLETTNER
}

\section{OVERVIEW}

A substantial increase in the range, significance and impact of corporate social and environmental initiatives in recent years suggests the growing materiality of sustainability. Corporate social and environmental responsibility (CSR) appears to becoming established in many corporations as a critical element of strategic direction, and one of the main drivers of business development, as well as an essential component of risk management. CSR seems to be rapidly moving from the margins to the mainstream of corporate activity, with greater recognition of a direct and inescapable relationship between corporate governance, corporate responsibility, and sustainable development.

Questions are often addressed to the sincerity of corporate social and environmental initiatives; the legality of company directors engaging in these concerns; equally, the legality of the trustees of investment institutions attending to these interests; and the verifiability of CSR activities and outcomes. The aim of this chapter is to clarify the continuing and emerging legal and commercial basis for corporations to pursue corporate social and environmental responsibility; the ongoing legal and material support for institutional trustees to prioritize socially and environmentally responsible investments; to examine developments in verification on corporate reporting of CSR performance.

The chapter outlines the tensions between the promise of corporate initiatives in CSR and the significance of mandatory regulation. There may well be the case that further legislative and regulatory intervention will be required to ensure all corporations fully respond to the growing public demand that they recognize their wider social and environmental responsibilities. However it is useful to examine how far CSR objectives can be achieved within existing law and regulation. 


\section{THE GLOBAL SIGNIFICANCE AND IMPACT OF CORPORATE SOCIAL RESPONSIBILITY}

Corporate social and environmental responsibility (CSR) is rapidly moving from the margins to the mainstream of corporate activity, with greater recognition of a direct and inescapable relationship between corporate governance, corporate responsibility, business performance and sustainable business development.

Corporate social responsibility is receiving considerably increased attention world-wide and is associated with significant economic, environmental and social benefits. It is important to learns from this international experience as well as from local initiatives. The burgeoning importance of this newly revived movement for corporate responsibility and sustainability is demonstrated by the current frequency and scale of activity at every level (Calder and Culverwell 2005:43).

Among international organizations the United Nations is coordinating a public-private partnership between UNEP and 170 banks, insurers and asset managers world-wide including Deutsche Bank, Dresdner Kleinwort Wasserstein, Goldman Sachs, HSBC and UBS to explore the financial materiality of environmental, social and governance (ESG) issues to securities valuation (UNEP 2004a). Early in 2005 the UN convened a group of 20 of the world's largest institutional investors from 12 countries to negotiate a set of Principles of Responsible Investment, published in early 2006 as a guide to the investment community on how to incorporate environmental, social and governance issues into their investment decision-making and ownership processes. This document 
was launched at the New York Stock Exchange in April 2006 sets out six aspirational principles of responsible investment. In the document's introduction, Kofi Annan neatly sums up the main issue hindering companies' efforts at CSR:

"One of the main problems has long been the troubling disconnect between corporate responsibility as a broadly stated management imperative, and the actual behaviour of financial markets, which are too often guided primarily by short-term considerations at the expense of longer-term objectives.'

The six principles are designed to help solve this problem. Principle one states, "We will incorporate ESG issues into investment analysis and decision-making processes”. The other principles go on to back this up through commitments to request ESG disclosure, promote the principles and report on their implementation.

There are three main categories of signatory to the UN principles: asset owners, investment managers and professional service partners. At the time of writing, there were a total of 217 signatories representing 8 trillion US dollars. Australian representation is fairly impressive with 12 Australian super funds, 9 Australian investment managers and 4 Australian professional service partners already signed up to the principles. That means Australia makes up just over $11 \%$ of signatories worldwide, although we do not know what proportion of overall funds this represents. 
This recent work of the UNEP Finance Initiative builds on the work of the UN Global Compact which achieved more than 1,500 corporate signatories, working with the world's leading stock exchanges and the World Federation of Exchanges to advance the principles of corporate responsibility in capital markets and with public corporations (UN 2000). The Global Compact outlined a set of basic principles of human rights, labour and the environment which manifested a commitment to civilization, decency and responsibility on the part of investors and corporations.

In 2005 institutional investors representing 21 trillion dollars in assets came together for the third Carbon Disclosure Project meeting, collectively requesting the world's largest corporations to disclose information on greenhouse gas emissions and their approach to the management of carbon risks (UNEP FI 2005a). Finally, 36 of the world's largest banks, representing more than $80 \%$ of the global project finance market, have adopted the Equator Principles, a set of voluntary principles outlining environmental, social and human rights disciplines associated with project finance above \$50 million (Freshfields Bruckhaus Deringer 2005a). The principles originally were developed by the International Finance Corporation (IFC), the private sector investment arm of the World Bank.

The OECD also is active in the promotion of corporate social responsibility in its guidelines for the operations of multinational corporations; and the European Union is actively encouraging corporate social responsibility as the business contribution to sustainable development (OECD 2000; European Commission 2003;2004). At the 
national level a growing number of governments in Europe, and across the globe, have identified strongly with the call for corporate social and environmental responsibility, even with the evident difficulties in applying the Kyoto Protocol and creating an effective international climate policy regime.

At the corporate level the World Business Council for Sustainable Development, and World Economic Forum Global Corporate Citizenship Initiative has projected corporate responsibility in the minds of the international business elite (WBCSD 2002;2004 ; WEF 2005). The World Business Council for Sustainable Development published Beyond Reporting: Creating business value and accountability (2005) which was co-authored by several large companies and thus has a fairly unique perspective on CSR. The report delves into the detail of how CSR should be integrated across different business functions and not simply delegated to a specialist unit. It suggests that value can only be created if the majority of employees understand how to frame business challenges in a way that links with an overall sustainability agenda. Using company case studies, the report gives examples of how CSR can become value-driving rather than compliance-driven.

Other business organizations active in promoting CSR include the Business Leaders Initiative on Human Rights, the Conference Board, Business in the Community, and Business for Social Responsibility. A large number of leading corporations have signed up for the Global Reporting Initiative and more than 2,000 international corporations now publish reports on their CSR performance (many accessible on www.csrwire.com) (GRI 2002). Reinforcing the new found willingness on the part of corporate executives to 
disclose their commitments to CSR are the new indices including the Dow Jones Sustainability Index and FTSE4Good. Finally there are a proliferating number of consultancies, NGOs and campaign groups offering guidance and actively monitoring CSR activities along the entire length of the global value chain (World Bank 2003).

Questions are often addressed concerning the sincerity of corporate social and environmental initiatives; the legality of company directors engaging in these concerns; equally, the legality of the trustees of investment institutions attending to these interests; and the verifiability of CSR activities and outcomes. It is intended in this paper to briefly clarify the continuing and emerging legal and commercial basis internationally for corporations to pursue corporate social and environmental responsibility; the ongoing legal and material support for institutional trustees to prioritize socially and environmentally responsible investments; to examine developments in verification on corporate reporting of CSR performance; and to consider some illustrations of current best practice.

\section{THE INTEGRITY OF CSR}

Despite the recent burst of enthusiasm for corporate social and environmental responsibility in some quarters of the business community, the concept and practice still provoke a degree of understandable skepticism, (partly due to CSR's record of lapsing into apologetics for unacceptable corporate behaviour) (Najam 2000; Christian Aid 2004; Corporate Responsibility Coalition 2005; OECD Watch 2005). David Vogal in a review conducted for the Brookings Institute, The Market for Virtue: The Potential and Limits of 
CSR (2005), contends there are many reasons why companies may choose to behave more responsibly in the absence of legal requirements to do so, including strategic, defensive, altruistic or public spirited motivations. However despite pressure from consumers for responsibly made products, the influence of socially responsible investors, and the insistent call for companies to be accountable to a broader community of stakeholders there are important limits to the market for virtue:

"CSR is best understood as a niche rather than a generic strategy: it makes sense for some firms in some areas under some circumstances. Many of the proponents of corporate social responsibility mistakenly assume that because some companies are behaving more responsibly in some areas, some firms can be expected to behave more responsibly in more areas. This assumption is misinformed. There is a place in the market economy for responsible firms. But there is also a large place for their less responsible competitors. ..Precisely because CSR is voluntary and market-driven, companies will engage in CSR only to the extent that it makes business sense for them to do. Civil regulation has proven capable of forcing some companies to internalize some of the negative externalities associated with some of their economic activities. But CSR can reduce only some market failures” (2005:3-4).

Vogal concludes that CSR has a multidimensional nature, and that companies, like individuals, do not always exhibit consistent moral or social behaviour, and may behave better in some countries than others depending on the social and environmental policies existing there. Since the origins of industrialism there have always been more or less 
responsible firms, and though it may be heartening that executives in many highly visible firms may becoming more responsive (if only as a result of external stakeholder pressures) the reality is that the amounts wasted on the losses due to financial fraud, and the very substantial - and some would argue unwarranted - increases in executive compensation in corporations in the recent period far exceed any resources companies have devoted to CSR.

In a similar vein Deborah Doane who is Chair of the Corporate Responsibility Coalition in the UK, is skeptical regarding optimism about the power of market mechanisms to deliver social and environmental change, referring to the key myths informing the CSR movement as:

- The market can deliver both short-term financial returns and long term social benefits.

- The ethical consumer will drive change.

- There will be a competitive 'race to the top' over ethics amongst businesses.

- In the global economy countries will compete to have the best ethical practices.

In support of her argument these are largely mythological trends she highlights the insistence of stock markets upon short term results, and the failure of companies to invest in long term benefits; the considerable gap between green consciousness expressed by consumers and their consumer behaviour; the inconsistency between companies alignment to CSR schemes and their successful efforts to bring about the sustained fall in corporate taxation in the United States and other jurisdictions in recent decades; and 
finally the evidence emerging in developing countries of governments competing to reduce their insistence on the observance of social and environmental standards to attract international investment (Doane 2005).

It may well be the case that further legislative and regulatory intervention will be required to ensure all corporations fully respond to the growing public demand that they recognize their wider social and environmental responsibilities. However it is useful to examine how far CSR objectives can be achieved within existing law and regulation. If there is substantial evidence of leading corporations demonstrating it is possible to voluntarily commit to social and environmental performance and to achieve commercial success perhaps because of, rather than in spite of, ethical commitments - then it will be more straightforward to press for the legislative changes necessary to deal with corporations that refuse to acknowledge their wider responsibilities, as well as finding appropriate legislative support for companies that wish to develop further their CSR commitments.

In the meantime the practical fact is that corporations and governments currently are struggling with an "almost bewildering array of international CSR initiatives" (Calder and Culverwell 2005:7; McKague and Cragg 2005). Reviewing the efforts to develop CSR following the World Summit on Sustainable Development, a survey by the Royal Institute for International Affairs of stakeholders from governments, businesses and civil society groups identified a range of significant weaknesses in current approaches to promoting CSR which governments should seek to address: 
- An over-proliferation of CSR initiatives at the international level and lack of clarity about how these initiatives relate to each other in a coherent way;

- An excessive focus on getting businesses to make commitments to CSR and not enough focus on enabling them to implement them effectively;

- An absence of credible monitoring and verification processes of CSR initiatives;

- A lack of effective mechanisms of redress for communities affected by companies that flout national or international norms on sustainable development or human rights;

- A lack of engagement with developing country governments and their sustainable development priorities (e.g. economic development and poverty reduction);

- A failure to bridge the governance gap created by weak public sector governance of the private sector in many developing countries;

- The limited impact on national and international sustainable development goals;

- A lack of government involvement and/or investment in international CSR initiatives, which is contributing significantly to their underperformance (Calder and Culverwell 2005:7).

\section{DEFINING SOCIAL AND ENVIRONMENTAL SUSTAINABILITY}

The rapidly developing interest in sustainability and corporate social and environmental responsibility has resulted in a plethora of definitions and interpretations of the two concepts from international agencies, consultancies and practitioners (Calder and Culverwell 2005; McKague and Cragg 2005). A first difficulty is that the most commonly employed acronym CSR refers to corporate social responsibility, though in 
most interpretations is meant to include environmental responsibility also. The use of the simpler term corporate responsibility and acronym CR is not in widespread, though it would more readily embrace all corporate responsibilities. The UN's recent adoption of the environmental, social and governance (ESG) acronym may become influential, since it explicitly links governance to social and environmental responsibility.

More confusingly still, in some definitions CSR is subsumed under sustainability, while in others sustainability is included within CSR. One source of this confusion is that often different levels of analysis are being addressed. At the highest level the sustainability of the planet is at issue, and at lower levels the sustainability of economies and societies, industries and organizations. Corporate sustainability is a critical issue because of the economic scale and significance of these entities and their growing impact on the economy, society and environment. "Corporations have magnified capacities relative to individuals, in their financial resources, scale of operations, organizational capacity and capacity for social and individual harm” (Redmond 2005:1) Once the primary (in some cases sole) concern was to produce goods and services that might generate the profits to achieve the financial sustainability of the corporation (everything else was written off as externalities).

Increasingly today the social and environmental impact of the corporation will be assessed in deciding whether it is viable or not, by governments, regulators, or other stakeholders, even if the corporations’ management are reluctant to make this assessment. The license to operate can no longer be readily assumed for any corporation, and in an 
increasing number of contexts needs to be earned with verifiable evidence of the social and environmental responsibility of the corporation.

Definitions of CSR and sustainability range from the basic to the most demanding, from a specific reference to a number of necessary activities to demonstrate responsibility, to a general call for a comprehensive, integrated and committed pursuit of social and environmental sustainability. The following representative range of definitions of CSR is broadly in ascending order from the least to the most demanding:

- The integration of stakeholders' social, environmental and other concerns into a company's business operations (EIU 2002:2)

- The commitment of businesses to contribute to sustainable economic development by working with their employees, their families, the local community and society at large to improve their lives in ways which are good for business and for development ( World Business Council for Sustainable Development 2002).

- Corporate social responsibility is at heart a process of managing the costs and benefits of business activity to both internal (for example, workers, shareholders, investors) and external (institutions of public governance, community members, civil society groups, other enterprises) stakeholders. Setting the boundaries for how those costs and benefits are managed is partly a question of business policy and strategy and partly a question of public governance (World Bank 2002:1). 
- A concept whereby companies integrate social and environmental concerns in their business operations and in their interaction with their stakeholders on a voluntary basis (EU2001).

- A company's commitment to operating in an economically, socially, and environmentally sustainable manner, while recognizing the interests of its stakeholders, including investors, customers, employees, business partners, local communities, the environment, and society at large (Certified General Accountants Association of Canada 2005:20).

- CSR is essentially about how the company makes its profits, not only what it does with them afterwards. CSR is about how the company manages first, its core business operations - in the boardroom, in the workplace, in the marketplace, and along the supply chain; second, its community investment and philanthropic activities; and third, its engagement in public policy dialogue and institution building (Kennedy School of Government Corporate Responsibility Initiative: 2004:33)

- A business approach embodying open and transparent business practices, ethical behaviour, respect for stakeholders and a commitment to add economic, social and environmental value (SustainAbility 2005).

- Sustainability performance refers to an organisation's total performance, which might include its policies, decisions, and actions that create social, environmental and/or economic (including financial) outcomes (AccountAbility 2005:10). 
Sustainability as a whole (planet, environment, species) is an altogether more ambitious project with more expansive definitions than CSR. Corporations have a vital role to play in this also, beginning with a modest recognition of their necessary subordination to the interests of maintaining a balanced ecosystem. Sustainability is defined as:

- Meeting the needs of the present generation without compromising the ability of future generations to meet their needs (Bruntland Commission 1987)

- Sustainable development, sustainable growth, and sustainable use have been used interchangeably, as if their meanings were the same. They are not. Sustainable growth is a contradiction in terms: nothing physical can grow indefinitely. Sustainable use, is only applicable to renewable resources. Sustainable development is used in this strategy to mean: improving the quality of human life whilst living within the carrying capacity of the ecosystems (IUCN, UNEP, WWF 1991).

Putting the entire field into perspective, according to the Global Reporting Initiative (GRI) 2002 Sustainability Reporting Guidelines:

- environmental impact means an organization’s impact on living and non-living natural systems, including eco-systems, land, air and water. Examples include energy use and greenhouse gas emissions

- social impact means an organization's impact on the social system within which it operates. This includes labour practices, human rights and other social issues 
- economic impact means an organization's impact both direct and indirect on the economic resources of its stakeholders and on economic systems at the local, national and global levels.

The world has reached the limits of the paradigm of the freedom of business to destroy in the name of wealth generation. For example with regard to the environment the Stern Review of the Economics of Climate Change (2006) has definitively stated: "The scientific evidence is now overwhelming: climate change is a serious global threat, and it demands an urgent global response...The evidence gathered by the Review leads to a simple conclusion: the benefits of strong and early action far outweigh the economic costs of not acting. Climate change will affect the basic elements of life for people around the world -access to water, food production, health, and the environment. Hundreds of millions of people could suffer hunger, water shortages and coastal flooding as the world warms. Using the results from formal economic models, the Review estimates that if we don't act, the overall costs and risks of climate change will be equivalent to losing at least $5 \%$ of global GDP each year, now and forever. If a wider range of risks and impacts is taken into account, the estimates of damage could rise to $20 \%$ of GDP or more.”

Corporate objectives described as wealth generating too frequently have resulted in the loss of well being to communities and the ecology. But increasingly in the future the licence to operate will not be given so readily to corporations and other entities. A licence to operate will depend on maintaining the highest standards of integrity and practice in corporate behaviour. Corporate governance essentially will involve a 
sustained and responsible monitoring of not just the financial health of the company, but the social and environmental impact of the company.

As Sustainable Asset Management Group (SAM) (2003:5) argue 'Understanding the implications of these trends on business is central to sustainability investing as, despite lower interest rates, increased risk-premia have effectively erased the benefits of low costs of capital for business. The implications of environmental degradation and weakened eco-system have been starkly demonstrated by the spiralling costs of environmental catastrophes. Financial losses due to natural disasters have doubled each decade since the 1950s, and UNEP estimates that natural disasters caused by climate change could cost US\$ 150 billionn a year by 2012. Socio-cultural disruptions have also had severe financial implications recently: insurers had to cover US\$40 billion in losses after the September $11^{\text {th }}$ disaster.” This leads SAM (2003:2) to conceiving of a hypothesis of enlightened self-interest: "Should extreme climactic events such as flooding occur, the civility of society is disrupted and hence the healthy functioning of the economy undermined. This impacts the possibility of a vigorous population of enterprises thriving which, in turn, compromises the possibility of successful investment. Sustainability investing therefore selects companies that contribute to the vibrancy of the socio-economic system and a sustainable planet.'

In the past companies did not recognise or acknowledge the environmental and social effects of their operations, such as the impacts of releases to water have on river systems, or the effects of particular emissions upon human health. The United States 
Environmental Protection Agency (1995:1) has developed a useful dichotomy - private versus social costs. The term environmental cost has at least two major dimensions: it can refer solely to costs that directly impact a company's bottom line (termed private costs) or it can also encompass the costs to individuals, society, and the environment for which a company is not directly accountable (termed societal costs by the EPA but typically referred to as externalities). "Externalities generated by an organisation, although possibly ignored from an accounting perspective, are often recognised as costs by other entities.” (ICAA 2003:19) Consideration of the range of environmental costs an entity might be encouraged to consider widens the scope of accounting systems, though makes measurement more difficult.

Together the trends indicated provide the context in which business must operate in future suggest the following imperatives which all corporations will face:

- Maintaining a licence to operate via transparency and accountability

- Serving society

- Generating more value with less impact

- Preserving the resource base

- Doing business in a networked world.

In summary the challenge is to find means of enduring value creation without social or environmental harm. As the Economist has recently noted, "Everybody's Green Now," even the big American energy companies that resisted environmental awareness most fiercely, are facing up to the realities of emerging carbon markets (Economist 2 June 2007). 


\section{FROM THE MARGINS TO THE MAINSTREAM?}

However challenging the prospects, there are growing indications of large corporations taking their social and environmental responsibilities more seriously, and of these issues becoming more critical in the business agenda. KPMG since 1993 have conducted an international survey of corporate responsibility every three years which has revealed the developing prevalence of this commitment. Surveying the largest 100 companies in a sample of advanced industrial OECD countries (with the addition of the Global 250 companies from 1999), KPMG (2005) find a steadily rising trend in companies issuing separate corporate responsibility annual reports. From 13\% of national 100 companies reporting on corporate responsibility matters in 1993, by 2005 this had risen to 33\% (up to $41 \%$ if including information in annual reports). A more substantial increase in the Global 250 reporting occurred with 35\% reporting in 1999 and 52\% in 2005 (64\% including information in annual reports). Publication of corporate responsibility reports as part of the annual financial reports of companies often implies the issue is regarded as of greater salience, and companies often progress from separate to integrated CSR and financial reports.

More importantly, the substance of company reports is changing, from purely environmental reporting up until 1999, to sustainability reporting (social, environmental and economic), which has become the mainstream approach of the G250 companies, and is becoming so among the national 100 companies. The two leading countries in terms of 
separate corporate responsibility reporting are Japan (80\% of top 100 companies) and the UK (71 \% of top 100 companies) in 2005. The industrial sectors with the highest environmental impact tend to lead in reporting (in one sense self-evidently important, in another sense deeply curious). At the Global 250 level over 80\% of companies report in electronics and computers; utilities; automotive; and oil and gas sectors. The most remarkable increase in the Global 250 was in the finance sector, with a doubling of the rate of CSR reporting from 24\% in 2002 to $57 \%$ in 2005 . At the national level over 50\% of top 100 companies are reporting in utilities; mining; chemicals and synthetics; oil and gas; and forestry and paper sectors.

Finally the KPMG survey reveals a balanced range of business drivers for CSR reporting, beginning with economic considerations (74\% of companies); ethical considerations (54\%); innovation and learning (53\%); employee motivation (47\%); risk management (47\%) and access to capital (39\%). The survey suggests there were solid business reasons for acting and reporting on CSR: "The economic reasons were either directly linked to increased shareholder value or market share or indirectly linked through increased business opportunities, innovation, reputation, and reduced risk. Thirty-nine per cent of the companies reported improved shareholder value, and one in five (21 per cent) reported increased market share as an important reason for sustainability” (KPMG 2005:18). 
In a further recent international survey of 136 corporate executives and 65 executives of institutional investors on the importance of corporate responsibility (CR) the Economist Intelligence Unit (EIU) discovered a similar growth in interest:

“A total of $88 \%$ of executives said that CR is a 'central' or 'important' consideration in decision-making. This compares with $54 \%$ of executives who said it was a 'central' or 'important' consideration five years ago. The biggest percentage change between now and five years ago was among European executives. A total of $46 \%$ said CR was 'central' or 'important' five years ago compared with $84 \%$ at the present time. In Asia, the proportion rose from $49 \%$ to $82 \%$ and in North America from $66 \%$ to $88 \%$. The survey of professional investors reveals a sharper trend. Eighty-one percent of those surveyed said CR was currently a 'central' or 'important' consideration in their investment decisions, compared with $34 \%$ who said it was 'central' or 'important' five years ago. In fact, $14 \%$ of them said CR was not a consideration at all five years ago. Now, not a single investor said it was not a consideration.” (EIU 2005:5)

As with the gap noticed earlier between consumer consciousness and behaviour, it is likely there will be a mighty gap between the expressed concerns of executives for corporate responsibility and their actual behaviour in different circumstances in the exigencies of difficult situations, however simply expressing concerns is an advance over stony faced refusals to even acknowledge responsibilities that may have occurred in the past. "Corporate responsibility is really about ensuring that the company can grow on a sustainable basis, while ensuring fairness to all stakeholders," says N R Murthy, the 
chairman of an Indian IT firm, Infosys” (EIU 2005:2). Though some of the expressed concern may be part of the discourse of political correctness, there does appear to be a significant shifting of opinion among executives, as the EIU comments:

"Until recently, board members often regarded corporate responsibility as a piece of rhetoric intended to placate environmentalists and human rights campaigners. But now, companies are beginning to regard corporate responsibility as a normal facet of business and are thinking about ways to develop internal structures and processes that will emphasize it more heavily. In the not-too-distant future, companies that are not focusing on corporate responsibility may come to be seen as outliers. As companies focus on nonfinancial performance, an important yardstick of corporate responsibility, the measurement of intangibles, such as customer satisfaction and employee morale, are likely to become less vague and more credible” (EIU 2005: 3).

One of the surprising results of the EIU survey was that after more than a decade of the exhortation of the primacy in all circumstances of shareholder value, the executives surveyed still possessed a balanced appreciation of the relative importance of key stakeholders to the company, identifying customers, employees and shareholders in that order. The EIU compiled some of the contextual highlights for these changes in executive views in the emerging evidence that corporate social and environmental responsibility is moving substantially from the margins to the mainstream of economic activity: 
- “The New York-based GovernanceMetrics International (GMI), which covers corporate governance and CR, now produces in-depth rating reports on 2000 companies around the world and has a growing client base including TIAACREF, State Street Bank and ABP, the largest pension fund in Europe.

- More than 10,000 individuals and 3,000 listed companies have helped to develop the standards of the Global Reporting Initiative (GRI), an organisation based in Amsterdam, trying to create a single global measure for CR performance. Among its corporate clients implementing GRI standards are Bayer, Canon, Deutsche Bank, General Motors, Heineken and Shell.

- A group of five major European institutional investors, including the secondlargest pension fund in the UK and the largest pension fund in the Netherlands, jointly stated in October 2004 that they would allocate 5\% of their budgets for the purchase of non-financial research analysis of such topics as corporate governance, labour management and environmental practices.

- One in every nine investment dollars under professional management in the US is now invested in socially responsible funds. This amounts to US\$2 trillion (trillion) out of a total of US\$19 trillion in investible funds, according to the 2003 report on socially responsible investing (SRI) produced by the Social Investment Forum, the national trade body for the SRI industry.” (EIU 2005:4-5) 
At the confluence of these multiple emerging initiatives and trends towards greater corporate social and environmental responsibility there is emerging a dynamic stakeholder model for driving enlightened shareholder value. At many leading corporations the pieces of what admittedly is a very large and demanding puzzle are beginning to come together. The wider commitments to building engaged and inclusive relationships with employees, economic partners, the community and the environment becomes a means of achieving enlightened shareholder value through access to a lower cost of capital, enhanced reputation, minimized risks and new business opportunities.

\section{CORPORATIONS ENLIGHTENED SHAREHOLDER VALUE? THE DUTY TO PROMOTE THE SUCCESS OF THE COMPANY}

The impact of the adoption of corporate commitments to wider forms of social and environmental engagement and reporting will be determined essentially by initiatives of leading companies and, in turn, this will be influenced by the insistent pressures companies encounter from the market, investors and stakeholders, and the perceived commercial benefit of assuming a broader accountability. However, the role of the law and of accounting standards in establishing a framework of accountability and management discipline is a significant factor. Historical analysis of the perception of company directors' duties, including legal interpretations, reveals much greater sympathy for corporations adopting a wider view of their responsibilities than the recently imposed tenets of shareholder value would suggest. 
This balance of pursuing market opportunities while maintaining accountability has proved a defining challenge for business enterprise since the arrival of the joint-stock company in the early years of industrialism. The accountability and responsibility of business enterprise was constantly subject to question, and historically failed this test often in the view of the public. Maurice Clark deplored how business "inherited an economics of irresponsibility” from the laissez-faire beliefs and practices of early industrialism (1916). He argued business transactions do not occur in isolation, but have wider social and economic consequences that need to be considered, impacting directly on employment, health and the environment. He insisted legal regulation may be required to ensure protection from abuses, but that this could never replace a general sense of responsibility in business that goes beyond the letter of the law, preventing competitive forces leading to a race to the bottom. Hence the periodic outbreak of destructive competition needed to be restrained in Clark's view by "an economics of responsibility, developed and embodied in our working business ethics (1916).”

The debate concerning the true extent of the accountability and responsibility of business enterprise has continued to the present day, punctuated by occasional public outrage at business transgressions, and calls for greater recognition of the social obligations of business. At the height of the economic depression in the United States in 1932 Dodd made a dramatic plea in the pages of the Harvard Law Review, “...There is in fact a growing feeling not only that business has responsibilities to the community but that our corporate managers who control business should voluntarily and without waiting for legal compulsion manage it in such a way as to fulfill these responsibilities” This resonated 
with Berle and Means insistence that large corporations "serve not alone the owners or the control, but all society.” Though Berle subsequently commenced a prolonged debate with Dodd on the subject of "For Whom Are Corporate Managers Trustees”, Berle (1955) later conceded to Dodd's argument that management powers were held in trust for the entire community (Wedderburn 1985:6)

Such forthright views did not remain at the level of academic speculation, but often were translated into legal, policy and business interpretations and practice. For example in Teck Corp Ltd v Millar, the Supreme Court of British Columbia, while retaining the identification of company interests with those of shareholders, nonetheless was prepared to grant directors a license under their fiduciary duties to take into account wider stakeholder interests:

“The classical theory is that the directors' duty is to the company. The company's shareholders are the company ... and therefore no interests outside those of the shareholders can legitimately be considered by the directors. But even accepting that, what comes within the definition of the interests of the shareholders? By what standards are the shareholders' interests to be measured? A classical theory that once was unchallengeable must yield to the facts of modern life. In fact, of course, it has. If today the directors of a company were to consider the interests of its employees no one would argue that in doing so they were not acting bona fide in the interests of the company itself. Similarly, if the directors were to consider the consequences to the community of any policy that the company intended to pursue, and were deflected in their commitment 
to that policy as a result, it could not be said that they had not considered bona fide the interests of the shareholders” (Teck Corp Ltd v Millar 1973:313-4).

Wedderburn (1985:12) documents an equivalent deep-seated and practical commitment of corporate responsibility to a wide constituency in the post-war beliefs of leaders of the British business community. A lively debate continues worldwide concerning the scope of directors' duties. In Australia the Corporations Act Section 181 obliges directors and other corporate officers to exercise their powers and discharge their duties

- In good faith and in the best interests of the corporation

- For a proper purpose.

Under common law directors are obliged to act in the interests of 'the company as a whole.' Traditionally this phrase has been interpreted to mean the financial well being of the shareholders as a general body. (Though directors are obliged to consider the financial interests of creditors when the firm is insolvent or near-insolvent). A recent generation of financial economists helped to translate this broad shareholder primacy principle into a narrow pursuit of shareholder value. There is a wider interpretation of shareholder value which suggests that only when all of the other constituent relationships of the corporation - with customers, employees, suppliers, distributors and the wider community - are fully recognized and developed that long term shareholder value can be released. However the restrictive definition of shareholder value has often been associated with short-termism and a neglect of wider corporate responsibilities in the interests of immediate profit maximization. Concerns have arisen that directors who do wish to take account of other stakeholder interests may be exposed. 
Traditionally, commercial law in many European countries has supported a sense of the wider social and environmental obligations of companies, which continues despite a recent enthusiasm for the principle of shareholder value as some large European companies for the first time seek the support of international investors. The UK has stood apart from Europe as an influential exponent of the Anglo-American market based approach to corporate governance. However in an effort to jettison the company law rhetoric formed in the $19^{\text {th }}$ century, and to make the law more accessible a Company Law Review (CLR) steering group was established. The ensuing consultative document Modern Company Law for a Competitive Economy: Developing the Framework (2000) proposed for the first time that there should be a statutory statement of directors duties (presently the core components of those duties is found in case law), and made a significant step in the direction of endorsing fuller corporate social and environmental reporting:

“...Current accounting and reporting fails to provide adequate transparency of qualitative and forward looking information which is of vital importance in assessing performance and potential for shareholders, investors, creditors and others. This is particularly so in the modern environment of technical change, and with the growing importance of 'soft', or intangible assets, brands, know-how and business relationships. The full annual report must be effective in covering these, both as a stewardship report and as a medium of communication to wider markets and the public... we believe the time has come to require larger companies to provide an operating and financial review, which will cover 
the qualitative, or 'soft', or intangible, and forward looking information which the modern market and modern business decision making requires, converting the practice of the best run companies into a requirement for all.' (CLR 2000: 180-1)

These issues were extensively considered in the UK for several years in the deliberations of the Modern Company Law Review. Two approaches were considered:

- A pluralist approach under which directors duties would be reformulated to permit directors to further the interests of other stakeholders even if they were to the detriment of shareholders.

- An enlightened shareholder value approach allowing directors greater flexibility to take into account longer term considerations and interests of various stakeholders in advancing shareholder value.

In considering these approaches, the essential questions of what is the corporation, and what interests it should represent are exposed to light, as Davies eloquently argues:

"The crucial question is what the statutory statement says about the interests which the directors should promote when exercising their discretionary powers. The common law mantra that the duties of directors are owed to the company has long obscured the answer to this question. Although that is a statement of the utmost importance when it comes to the enforcement of duties and their associated remedies, it tells one nothing about the answer to our question, whose interests should the directors promote? This is because the company, as an artificial person, can have no interests separate from the interests of those 
who are associated with it, whether as shareholders, creditors, employers, suppliers, customers or in some other way. So, the crucial question is, when we refer to the company, to the interests of which of those sets of natural persons are we referring?” (2005:4).

As a member of the Corporate Law Review Steering Group Davies goes on to defend the enlightened shareholder value view suggesting the pluralist approach produces a formula which is unenforceable, and paradoxically gives management more freedom of action than they previously enjoyed. An Australian legal expert, Redmond endorses this critique of widening the scope of directors' duties too greatly:

“The pluralist or multifiduciary model rests on a social, not a property, view of the corporation. It identifies the corporate purpose with maximising total constituency utility. This is an indeterminate outcome measure which poses particular difficulties is translation into a legally enforceable duty. The indeterminacy of the criteria for decision and performance measurement also points to a probable loss of accountability for directors since it offers broad scope to justify most decisions. It is difficult to resist the conclusion of the UK review that either it confers a broad unpoliceable policy discretion on managers themselves or must gives a broad jurisdiction to the courts. The model needs either practical rehabilitation or a superior performance metric. It is not clear where either might be found” (Redmond 2005:27). 
In the resulting UK Company Law Reform Bill (2005) the enlightened shareholder value view has prevailed in Clause 156, which defines the essential directoral duty as:

Duty to promote the success of the company

(1) A director of a company must act in the way he considers, in good faith, would be most likely to promote the success of the company for the benefit of its members as a whole.

(2) Where or to the extent that the purposes of the company consist of or include purposes other than the benefit of its members, his duty is to act in the way he considers, in good faith, would be most likely to achieve those purposes.

(3) In fulfilling the duty imposed by this section a director must (so far as reasonably practicable) have regard to-

(a) the likely consequences of any decision in the long term,

(b) the interests of the company's employees,

(c) the need to foster the company's business relationships with suppliers, customers and others,

(d) the impact of the company's operations on the community and the environment, (e) the desirability of the company maintaining a reputation for high standards of business conduct, and

(f) the need to act fairly as between members of the company. 
(4) The duty imposed by this section has effect subject to any enactment or rule of law requiring directors, in certain circumstances, to consider or act in the interests of creditors of the company.

This clause replaces the discretion of directors to have regard for stakeholder interests with a duty for directors to do this:

“As far as directors' duties are concerned, this is the heart of the enlightened shareholder value approach. The aim is to make it clear that although shareholder interests are predominant (promotion of the success of the company for the benefit of its members), the promotion of shareholder interests does not require riding roughshod over the interests of other groups upon whose activities the business of the company is dependent for its success. In fact, the promotion of the interests of the shareholders will normally require the interests of other groups of people to be fostered. The interests of non shareholder groups thus need to be considered by the directors, but, of course, in this shareholder-centred approach, only to the extent that the protection of those other interests promotes the interests of the shareholders. The statutory formulation can be said to express the insight that the shareholders are not likely to do well out of a company whose workforce is constantly on strike, whose customers don't like its products and whose suppliers would rather deal with its competitors” (Davies 2005:5).

In this way the Company Law Reform Bill treads a fine legal line between a sense of 
'enlightened shareholder value' which is becoming best practice in many leading companies, and more radical claims for company law to adopt a more 'pluralist' sense of the ultimate objectives of the enterprise and the interests to be served. The reform manages this balancing act by suggesting that the pluralist objectives of maximising company performance to the benefit of all stakeholders can best be served by professional directors pursuing commercial opportunities within a framework of standards and accountability:

“... The overall objective should be pluralist in the sense that companies should be run in a way which maximises overall competitiveness and wealth and welfare for all. But the means which company law deploys for achieving this objective must be to take account of the realities and dynamics which operate in practice in the running of commercial enterprise. It should not be done at the expense of turning company directors from business decisions makers into moral, political or economic arbiters, but by harnessing focused, comprehensive, competitive decision making within robust, objective professional standards and flexible, but pertinent accountability” (CLR 2000:14 ).

The reform supports the ultimate power of shareholders to appoint or dismiss directors for whatever reasons they choose, and to intervene in management to the extent the constitution permits, and confesses: “...There is clearly an inconsistency between leaving these powers of shareholders intact and enabling or requiring directors to have regard to wider interests...the effect will be to make smaller transactions within the powers of 
directors subject to the broad pluralist approach, but larger ones which are for shareholders subject only to the minimal constraints which apply to them" (CLR 2000: 26)

The United Kingdom Company Law Review (2000) in its comprehensive review of company law recommended a recasting of directors' duties to give effect to its notion of “enlightened shareholder value” ultimately contained in the Companies Bill 2006 (UK) which received Royal Assent on 8 November 2006. The possibility that this will be accompanied by an extension of the requirements for company reporting to include social and environmental matters may appear to have receded, with the UK Chancellor's dramatic abandonment of the obligatory Operating and Financial Review for listed companies in November 2006. However this was in the context of the European Union's Accounts Modernization Directive (2003/51/EC) which also requires companies include environmental and social reports with their annual accounts necessary for an understanding of the companies performance. Many large UK corporations have continued with their intention to publish Operating and Financial Review's despite it no longer being mandatory. It is likely that these modern company law proposals will over time facilitate the wider and more conscious adoption by UK companies of social and environmental commitments, and the willingness to report fully on them. In time it is possible that such social and environmental commitments will become part of a widespread company and management best practice, in the way that the commitment to quality in the production of goods and services has become universal. 
Moreover just as the UK in the publication of the Cadbury Code of corporate governance ultimately influenced a considerable number of other countries to adopt a similar code, it is possible that other countries, particularly that share a common law tradition to the UK, will begin to review their company law with similar objectives in mind. The twin inquiries that took place into corporate responsibility in Australia are illustrative of this widening interest . The Corporations and Markets Advisory Committee (CAMAC) commenced in March 2005 to consider whether directors duties under the Corporations Act 2001 should include corporate responsibilities or obligations to take into account certain classes of stakeholders. The Committee published an excellent Discussion Paper on Corporate Social Responsibility (available free at www.camac.gov.au).

The second inquiry, the Parliamentary Joint Committee on Corporates and Financial Services (PJC) began in June 2005 with a call for submissions on corporate social responsibility, and has received over 120 extensive submissions from companies, consultancies, academics and other interested parties (available at http://www.aph.gov.au/Senate/committee/corporations_ctte/corporate_responsibility/inde $\underline{\text { x.htm). }}$ Together these inquiries served to raise awareness of the issues involved in corporate responsibility considerably in Australia.

The notion that a change in company law was required to clarify and strengthen directors duties on corporate social responsibility was rejected by both the Australian reviews, in favour of a range of voluntary measures. CAMAC concluded: "The Committee does not support the revision of the Corporations Act in the manner referred to in these questions. 
The established formulation of directors' duties allows directors sufficient flexibility to take relevant interests and broader community considerations into account. Changes of a kind proposed from time to time do not provide meaningful clarification for directors, yet risk obscuring their accountability” (2006:7). CAMAC went on to make a series of recommendations concerning the importance of disclosure, and encouraging responsible business practices. Similarly the PJC maintained, "The committee strongly supports further successful engagement in the voluntary development and wide adoption of corporate responsibility. The committee has formed the view that mandatory approaches to regulating director's duties and to sustainability reporting are not appropriate. Consequent on the recommendations of this report, the committee expects increasing engagement by corporations in corporate responsibility activities. This would obviate any future moves towards a mandatory approach. The committee believes that the recommendations contained in this report will play an important part in progressing the future of corporate responsibility in Australia” (PJC 2006:xix).

Both recent Australian official inquiries acknowledge that "Corporate responsibility in Australia is still in its developmental stages...” (PJC 2006:xix). Both inquiries stress the importance of monitoring the adoption of their recommendations, and that " There is scope for additional 'light touch’ measures by government, helping corporate and other participants where the opportunity arises, without constraining energy and initiative in the community marketplace” (CAMAC 2006:169). 
However, the role of the law and of regulation in establishing a framework of accountability and management discipline is a significant factor in concentrating attention on this matter. In this sense some might claim the recommendations of the two Australian committees of inquiry, however supportive of an enhanced engagement in CSR on the part of companies, represent a missed opportunity with regard to the ameliorative effect of legal and regulatory change. Company law reform in the UK treads a fine legal line between a sense of 'enlightened shareholder value' which is becoming best practice in many leading companies, and more radical claims for company law to adopt a more 'pluralist' sense of the ultimate objectives of the enterprise and the interests to be served, and in this way has served to move both policy and practice forward in a dynamic way.

One reason the agenda of corporate responsibility is increasingly irresistible is that while legal liability of corporations is deepening, what has been described as an emerging and hardening moral liability is exerting increasing influence. In this respect the legislative process lags behind what society thinks, values and respects. Moral liability occurs when corporations violate stakeholder expectations of ethical behaviour in ways that put business value at risk. There is an increasing convergence between these two forms of liability, as corporations come under scrutiny both by the law and - often more immediately and pointedly - by public opinion (SustainAbility 2004:5). A graphic illustration of this was the James Hardie building company which having moved its corporate headquarters from Australia to the Netherlands, and the majority of its business activity to the United States, believed it had escaped responsibility for the legal liabilities of its remaining Australian subsidiaries to the thousands of asbestos victims dependent on 
a seriously underfunded and almost bankrupt medical foundation Hardie had left behind to meet their claims. Massive public disapproval in Australia and internationally, and a commission of inquiry combined with the threat of legislative intervention, dragged James Hardie back to face the consequences of its irresponsible actions over many decades in the Australian market (Jackson 2004).

Paul Redmond lays out clearly the critical parameters of a fundamental ongoing debate: "What should be the legal rule with respect to directors' duties? Should company law require directors and senior managers to act by reference to the interests of all stakeholders in the corporate enterprise, according primacy to no particular interests including those of shareholders (mandatory pluralism)? Or should company law permit (but not require) directors and senior managers to act by reference to the interests of all stakeholders, according primacy to no particular interests including those of shareholders (discretionary pluralism)? The most radical of these models is the mandatory pluralist model creating a multifiduciary duty requiring directors and managers to run the company in the interest of all those with a stake in its success, balancing the claims of shareholders, employees, suppliers, the community and other stakeholders. The claims of each stakeholder are recognised as valuable in their own right and no priority is accorded shareholders in this adjustment; their interest may be sacrificed to that of other stakeholders. (Stakeholders are variously defined as those with an interest in or dependence relationship with the company or, alternatively, as those upon whom it depends for its survival). The discretionary pluralist model would permit, but not require, directors to sacrifice shareholder interests to those of other stakeholders. One or other of 
these models would formalise the managerialist practice that has been displaced by the current shareholder value culture” (Redmond 2005)

\section{INVESTMENT INSTITUTIONS EFFECTIVE PORTFOLIO MANAGEMENT: THE DUTY TO ADDRESS ENVIRONMENTAL, SOCIAL AND GOVERNANCE ISSUES?}

Similar forces that are impressing corporations towards taking a greater regard of CSR issues are guiding investment institutions towards addressing environmental, social and governance issues more directly in their investment policies and practices. In the UNEP Finance Initiative on The Materiality of Social, Environmental and Corporate Governance Issues to Equity Pricing (2004) the interest of a growing number of institutional investors in approaches to asset management that explicitly include environmental, social and governance (ESG) criteria and metrics, either for ethical reasons or as relevant to investment performance was considered. Critical intermediaries are the brokerage firms that often have paid less consideration to ESG issues, often because they are driven by short term performance. A group of eleven international brokerage firms’ analysts were commissioned to examine a range of industry sectors regarding the relevance of ESG to investment performance, and to submit detailed reports. Briefly their conclusions were:

- Environmental, social and governance criteria affect shareholder value both in the short and long term, and in some cases the effects could be profound. Research to determine the financial materiality of these criteria 
should use longer time spans than is currently employed for financial analysis.

- Governments could reduce barriers to environmental, social and corporate governance analysis by mandating and standardizing the inclusion of these criteria in national and international corporate disclosure frameworks.

- Innovative techniques are being developed to perform financial analyses of environmental, social and corporate governance criteria in response to growing investor demand, including ranking surveys, portfolio analysis of best and worst performers, and scenario analysis to evaluate potential impact of upcoming regulation on sectors.

The survey discovered that brokerage houses in Europe are increasingly willing and able to respond to demand for ESG research. In contrast brokerage houses in the United States referred to perceived difficulty in analysis due to barriers associated with inadequate disclosure of these criteria.

A further fascinating research project of the UNEP Finance Initiative considered A Legal Framework for the Integration of Environmental, Social and Governance Issues into Institutional Investment (2005). The current value of assets managed by the investment industry worldwide is estimated at US\$42 trillion, pension fund assets in the US and UK alone amounting to US\$7.4 trillion. However the weighty responsibility of deciding where these assets are invested lies not with the owners, but with a small number of principals and agents. "By influencing the way investments are made, the legal factors that inform the decisions made by this relatively small group have a profound effect on 
the behaviour of the entities in which these assets are invested and ultimately on the environments and societies with which these investment vehicles interact (UNEP FI 2005:6).

Despite the increasing evidence that ESG issues do have a material impact on the financial performance of securities and increasing awareness of the importance of assessing ESG related risks, the effort to achieve a greater regard for ESG issues in investment decision-making is often resisted on the basis that institutional principals and their agents are legally prevented from taking account of these issues. Just as it is assumed corporate directors can only be committed to shareholder value, it is often assumed that investment trustees can only be directed towards profit maximization. However the survey conducted by the international law firm Freshfields Bruckhaus Deringer confirms categorically that in each of the jurisdictions examined (France, Germany, Italy, Japan, Spain, UK, US, Australia and Canada) investment decision makers retained some degree of discretion as to how they might invest the funds they control.

In the common law jurisdictions (US, UK, Australia and Canada) the rules are articulated in statute and in court decisions. In the other jurisdictions as civil law applies, rules are articulated as codes or in statutes. Though in none of the jurisdictions do rules prescribe how principals should integrate ESG considerations into their decisions, in most cases it is left to principals to determine their investment approach within their legal obligations. 
Fiduciary duties are the key discretionary limits of investment decision makers in common law countries, the most important duties being the duty to act prudently and the duty to act in accordance with the purpose for which investment powers were granted (the duty of loyalty).

In the US the modern prudent investor rule, which incorporates both a duty of care and a duty of loyalty, emphasizes modern portfolio theory and provides that:

- investments are assessed not in isolation but in the context of their contribution to a total investment portfolio;

- there is no duty to 'maximise' the return of individual investments, but instead a duty to implement an overall investment strategy that is rational and appropriate to the fund;

- the investment portfolio must be diversified, unless it is prudent not to do so; and

- the prudence of an investment should be assessed at the time the investment was made and not in hindsight.

The effect of the modern prudent investor rule is that institutional decision-makers are given latitude to follow a wide range of diversified investment strategies, provided their choice of investments is rational and economically defensible, they are free to construct a balanced portfolio (UNEP FI 2005:8). Other jurisdictions stipulate the duty to act conscientiously in the interests of beneficiaries, to seek profitability, recognize the portfolio approach to modern investment, and in some jurisdictions limits on the types of assets which may be selected for particular funds. 
Two things which are critical in all jurisdictions are following the correct process, and pursuing proper objectives in terms of acting only in the interests of the beneficiaries. As with other investment criteria, different considerations will be given different weight, according to how conditions are defined and analysed. In some circumstances it may be decided that ESG considerations have little material impact on financial performance relevant to a particular investment. However this does not justify failure to identify such considerations and to assess the weight. It is becoming increasingly difficult to argue that ESG considerations are difficult to quantify, since good will and intangibles are now readily quantified. A majority of the jurisdictions surveyed have already legislated to require investment decision makers, particularly of pension funds to disclose the extent to which they take ESG considerations into account.

There is increasingly credible evidence that ESG considerations have a vital role to play in the proper analysis of investment value, and cannot be ignored as they would result in investments being given inappropriate value for example: "Climate change is an obvious example of an environmental consideration that is recognised as affecting value. Following the recent release of a report by Mercer Investment Consulting noting the financial impact that climate change has already had on companies' costs, revenues, assets and liabilities, the UK Carbon Trust expressed the view that 'Pension fund trustees have a duty to address the financial risk posed by climate change when making investment decisions'” (UNEP FI 2005:11) 
Investment institutions are not only becoming more alert regarding the ESG issues in their investment portfolio they are also beginning to take a proactive stance in terms of engaging in the environmental, social and governance performance of the corporations they invest in. Both in the US and UK the traditional passivity of the investment institutions is being cast aside in favour of more active involvement. Certainly they continue to prefer quiet influence to open confrontation, but in an increasing number of instances the institutional investors have demonstrated a willingness to use their power to insist on higher standards of governance, and there are some indications this may occur more frequently in future on wider ESG issues.

\section{CORPORATE REPORTING OF CSR}

If the revival of interest in CSR is to continue to develop, and not descend into apologetics as previous efforts have done, and if the current wave of interest in ESG issues in the investment community is to bear fruit in more enduring returns, then what is absolutely critical is the accuracy and verifiability of corporate disclosure regarding CSR performance. In this regard the Global Reporting Initiative (GRI) Principles are an invaluable tool for working towards international confidence in the trustworthiness of corporate reporting. The overall aim of the GRI-based reporting is to:

- provide a balanced and reasonable representation of an organisation’s sustainability performance

- facilitate comparability

- address issues of concern to stakeholders 
The GRI reporting principles are the underpinnings of corporate report content, and as such are as important as the content itself. The reporting principles are:

- Transparency: Full disclosure of the processes, procedures and assumptions in report preparation are essential to its credibility.

- Inclusiveness: The reporting organisation should engage its stakeholders in preparing and enhancing the quality of reports.

- Auditability: Reported information should be recorded, compiled, analysed and disclosed in a way that enables internal auditors or external assurance providers to attest to its reliability.

- Completeness: All material information should appear in the report.

- Relevance: Reporting organisations should use the degree of importance that report users assign to particular information in determining report content.

- Sustainability Context: Reporting organisations should seek to place their performance in the broader context of ecological, social or other issues where such context adds significant meaning to the reported information.

- Accuracy: Reports should achieve a degree of exactness and low margin of error to enable users to make decisions with a high degree of confidence.

- Neutrality: Reports should avoid bias in selection and presentation of information and provide a balanced account of performance. 
- Comparability: Reports should be framed so as to facilitate comparison to earlier reports as well as to reports of comparable organisations.

- Clarity: Information should be presented in a manner that is understandable by a maximum number of users while still maintaining a suitable level of detail (GRI 2002:6).

Of course the Global Reporting Initiative is only one of a wide set of global principles, guidelines and standards. Hopefully over time greater coherence will be achieved in terms of globally accepted CSR principles, accounting principles, specialized CSR standards, and overall management systems as processes of normative and regulative change coalesce. The work of developing, implementing and verifying these reporting standards for corporate social and environmental responsibility will continue for many years to come, replicating the effort that is now being made in the quest to achieve better measurement and reporting of intangibles. However the whole edifice of CSR and ESG analysis and valuation will rest on the adequacy and rigour of reporting standards.

\section{FUTURE DEVELOPMENTS: THE REDESIGN OF THE CORPORATION}

It could be argued that the whole corporate social and environmental responsibility project, however worthy, is probably too little and too late. A more sympathetic view is that in its revived form CSR represents a new beginning in corporate reform that may be built on to create more substantial and enduring results. Certainly further efforts will be required to further ensure the accountability of corporations, on a universal and not 
simply voluntary basis. A group of business and community leaders in the US have projected a vision of Corporation 2020 based on the imperative to redesign the corporation. The principles they advocate are that the purpose of the corporation is to harness private interests to serve the public interest, that fair returns to shareholders should not be at the expense of the legitimate interests of other stakeholders, that corporations should operate sustainably, and that corporations distribute wealth produced equitably among those who contribute to the creation of that wealth. Robert Hinkley offers a 28 word amendment to directors duties which states that they are to act in the interests of the company "but not at the expense of the environment, human rights, public health and safety, dignity of employees, or the welfare of communities in which the corporation operates” (Luis 2005).

It is possible to envisage a business world not characterized by the bipolar disorder of the ongoing shareholder/stakeholder debate. The effective integration of corporate social and environmental responsibilities could potentially release greater value for both shareholders and wider stakeholders. Moving beyond compliance, to creating new value through new products and services that meet societal needs. Collaborating to solve the complex and demanding social and environmental problems that threaten to grow beyond our control. Corporations capable of working in investors, stakeholders, and societies interests in a collaborative, creative and productive way would require a fundamental redesign of the concept of the corporation and the institution of the market. At this stage both prospects appear remote. However we live in an industrial world where the problem of material production has essentially been solved. The primary remaining global 
dilemmas are that overproduction and massive surpluses still coexist with desperate poverty and need, and that the resource base for industry is rapidly depleting and damaging, potentially irreparably, the eco-system. It is possible that confronting these dilemmas will force the rethinking of corporate objectives, structures, and activities that is necessary. 


\section{REFERENCES}

AccountAbility (2005) Stakeholder Engagement Standard, London: AccountAbility

American Law Institute (1994) Principles of Corporate Governance: Analysis and Recommendations (Volume 1), American Law Institute Publishers

AMP Henderson Global Investors (2003) SRI Team Position Papers, AMP Henderson Global Investors

www.sustainablefuturefunds.com/research_position.asp

AMP Capital Investors (2005) Financial Payback from Environmental \& Social Factors, Sydney: AMP

Allouche J. (2006) Corporate Social Responsibility: Concept, Accountability and Reporting

Association of British Insurers (2004) Risk, Returns and Responsibility, London: Association of British Insurers, www.abi.org.uk

Australian Councils of Super Investors (2005) Corporate Social Responsibility: Guidance for Investors, Discussion Paper, September, Sydney: ACSI

Australian Stock Exchange (2003) Principles of Good Corporate Governance and Best Practice Recommendations, Sydney: Australian Stock Exchange

Baxt, R. (1976) The Duties of Directors of Public Companies - The Realities of Commercial Life, the Contradictions of the Law, and the Need for Reform, Australian Business Law Review, 4: 289

Bendell, J. (2004) Barricades and Boardrooms: A Contemporary History of the Corporate Accountability Movement, Geneva, United Nations Research Institute for Social Development, www.unrisd

Bendell, J. and Shah, R. (2002) Lifeworth 2002 Annual Review of Corporate Responsibility, January-March.

Bennet, M. James,P., (1998) The Green Bottom Line: Environmental Accounting for Management - Current Practices and Future Trends, Sheffield: Greenleaf Publishing

Berle, A.A. (1931) Corporate Powers as Powers in Trust, Harvard Law Review, 44: 1049

Berle, A.A. (1935) For Whom Corporate Managers are Trustees: A Note, Harvard Law Review, 45: 1365 
Berle, A.A. and Means, G.C. (1933) The Modern Corporation and Private Property, Commerce Clearing House

Berle, A.A. (1955) The $20^{\text {th }}$ Century Capitalist Revolution

Bielefeld, S., Higginson, S., Jackson, J. and Ricketts, A. (2004) Directors' duties to the company and minority shareholder environmental activism, Company and Securities Law Journal, 28:40.

Blair, M. and Stout, L. (1999) A Team Production Theory of Corporate Law, Vanderbilt Law Review, 85: 247

Blair, M. and Stout, L. (2001) Director Accountability and the Mediating Role of the Corporate Board, Washington University Law Quarterly, 79: 403

Blumberg, J., Korsvold,A., and Blum,G., (1996) Environmental Performance and Shareholder Value, Geneva: World Business Council for Sustainable Development

Brennan, G. (2002) Law Values and Charity, Australian Law Journal, 76: 492

Brill, H., Brill, J.A. and Feigenbaum, (2000) Investing With Your Values: Making Money and Making a Difference, New Society Publishers

Bruntland Commission (1987) Our Common Future, Oxford: Oxford University Press

Business Council of Australia (2001) Towards Sustainable Development - How Leading Australia and Global Corporations are Contributing to Sustainable Development, May, Sydney: BCA

Burritt,R., Hahn, T., Schaltegger,S., (2002) Towards a Comprehensive Framework for Environmental Management Accounting - Links Between Business Actors and Environmental Management Accounting Tools, Australian Accounting Review, Vol 12, No 2, 39-50

Calder, F. and Culverwell, M. (2005) Following up the World Summit on Sustainable Development Commitments on Corporate Social Responsibility, Royal Institute of International Affairs, London: Chatham House

Camejo, P (2002) The SRI Advantage: Why Socially Responsible Investing Has Outperformed Financially, New Society Publishers

Canadian Democracy and Corporate Accountability Commission, (2002) The New Balance Sheet: Corporate Profits and Responsibility in the 21st Century, Final Report, January 2002, 51 pp.

Canadian Democracy and Corporate Accountability Commission, (2001) An Overview of 
Issues, 49 pp.

Carbon Trust (2005) 'A Climate for Change: A Trustee's Guide to Understanding and Addressing Climate Risk’ www.thecarbontrust.co.uk

Certified General Accountants Association of Canada (2005) Measuring Up: A study on Corporate Sustainability Reporting in Canada, Vancouver: CGA

Clark, M (1916) “The Changing Basis of Economic Responsibility,” The Journal of Political Economy, 24, 3, 13-19, in, T.Clarke (ed), Corporate Governance Critical Perspectives on Business and Management, London: Routledge, 2005, pp45-60

Clarke, T. (2004) Theories of Corporate Governance, London: Routledge

Coles,D. and Green,D., (2002) Justpensions: Do UK Pension Funds Invest Responsibly?, www.justpensions.org

Committee on Public Finance, (2002) Corporate Social Responsibility and Socially Responsible Investment, Consultation Paper, Assemblee Nationale, Quebec, Secrétariat des commissions, May

Company Law Review Steering Group (2000) Modern Company Law For A Competitive Economy: Developing the Framework, London: Department of Trade and Industry

Co-operative Insurance (2002) Sustainability Pays

www.forumforthefuture.org.uk/publications/default.asp?pubid=16

Corfield, A. (1998) The Stakeholder Theory and its Future in Australian Corporate Governance: A Preliminary Analysis, Bond Law Review, 10: 213

Corporate Responsibility Coalition (2005) Corporate Social Responsibility in the Finance Sector in Europe, London: Corporate Responsibility Coalition (CORE)

Corporations and Markets Advisory Committee (2005) Corporate Social Responsibility: Discussion Paper, Sydney: Australian Government

Corporation of London, Financing the Future - The London Principles, www.cityoflondon.gov.uk/living_environment/sustainability/sustainable_finance.htm

CPA Australia (2005) Sustainability Reporting: Practices, Performance and Potential, Melbourne: CPA Australia

CSR Wire: The Corporate Social Responsibility Newswire Service http://www.csrwire.com/csr/index.mpl?arg=all 
Davies, P. (2005) Enlightened Shareholder Value and the New Responsibilities, WE Hearn Lecture at the University of Melbourne Law School, 4 October

Department of the Environment and Heritage, (2003) The Materiality of Environmental Risk to Australia's Finance Sector, Canberra: Commonwealth of Australia, www.deh.gov.au/industry/finance/publications/index.html

Department of the Environment and Heritage, (2003) The State of Public Environmental Reporting in Corporate Australia, Canberra: Commonwealth of Australia www.deh.gov.au/industry/finance/publications/index.html

Department of the Environment and Heritage (2003) Triple Bottom Line Reporting in Australia - A Guide to Reporting Against Environmental Indicators, Canberra:

Commonwealth of Australia www.deh.gov.au/industry/finance/publications/index.html

Department of the Environment and Heritage (2004) Triple Bottom Line Report: Our Environment, Social and Economic Performance, September, Australia

Digby, Q. and Watterson, L. (2004) Pursuing Profit, Productivity and Philanthropy: The Legal Obligations Facing Corporate Australia, Keeping Good Companies, June, Sydney: Chartered Secretaries Australia

Dion, M., (1998) Investissements Ethiques et Régie d'Entreprise, Entre la Mondialisation et la Mythologie, Médiaspaul, Coll. Interpellations, Montréal, 100 pp.

Doane, D. (2005) The Myth of CSR, Stanford Social Innovation Review, Stanford University Graduate School of Business, Fall 2005, 23-29

Dodd, E.M. (1932) For Whom are Corporate Managers Trustees? Harvard Law Review, 45: 1145, , in, T.Clarke (ed), Corporate Governance Critical Perspectives on Business and Management, London: Routledge, 2005, pp61-75

Dunphy,D., Griffiths,A., and Benn,S. (2003) Organizational Change for Corporate Sustainability, London:Routledge

Elkington, J. (1997) Cannibals with Forks: The Triple Bottom Line of $21^{\text {st }}$ Century Business, Oxford: Capstone Publishing Limited

The Equator Principles - A framework for banks to manage environmental and social issues in project financing www.equator-principles.com

Entine, J. (2003). The myth of social investing: A critique of its practice and consequences for corporate social performance research. Organization \& Environment, 16(3): 352-368 
Ernst \& Young (2002) Corporate Social Responsibility of Global Companies, New York: Ernst \& Young.

EIU (2005) The Importance of Corporate Responsibility, White Paper, The Economist Intelligence Unit Ltd

Environmental Resources Management, (2000) Erm Survey of UK Pension Funds, June 2000, 4 pp.

Ethical Investment Association (EIA) (2002) Socially Responsible Investment in Australia - 2002, www.eia.org.au

European Commission, (2001) Green Paper, Promoting a European Framework for Corporate Social Responsibility, Brussels: European Commision, July 18, 32 pp.

European Commission (2002) Corporate Social Responsibility: A Business Contribution to Sustainable Development, Brussels: European Union

EC (2002) Communication Concerning Corporate Social Responsibility: A Business Contribution to Sustainable Development, Brussels: European Union

European Commission (EC) (2003) Corporate Social Responsibility: A Business Contribution to Sustainable Development, Brussels: European Union

European Commission (2003) EU Multi-stakeholder Forum on Corporate Social Responsibility, Brussels: European Union

European Commission (2004) Corporate Social Responsibility: National Public Policies in the European Union, Brussels: European Union

Fayers,C., Cocklin,C. and Homes,D. (2000) Environmental Considerations in the Decisions of Austrlaian Investment Professionals, Journal of Environmental Assessment Policy Management, Vol 2, No 2

Feldman, S., Soyka, P., and Ameer, P., (1997) Does a Firm's Environmental Performance Result in a Higher Stock Price? Journal of Investing, Winter, 87-97

Freshfields Bruckhaus Deringer (2005a) The World Bank is Not Enough, Equator Principles Survey 2005 Part 1 The Banks, London: Freshfields Bruckhaus Deringer

Freshfields Bruckhaus Deringer (2005b) A Legal Framework for the Integration of Environmental, Social and Governance Issues into Institutional Investment, October 
Fujita, T., Kanai, T., Teranishi, K., Yamamoto, Y. and Nikko Citigroup (2004) The Global Environment and Socially Responsible Investment: Environmental Technologies Fuelling Zones of Growth, in, The Materiality of Social, Environmental and Governance Issues to Equity Pricing, 33-37, Geneva: UNEP

Gauthier, C. (2005) Measuring Corporate Social and Environmental Performance: The Extended Life Cycle Assessment, Journal of Business Ethics, 59: 199-206

Garz, H., Kudszus, V., Volk, C., and West LB AG (2004) Insurance and Sustainability: Playing with Fire in The Materiality of Social, Environmental and Governance Issues to Equity Pricing, 47-50, Geneva: UNEP

Gilles, V., Wright, A., Amusategui, L. Cipelletti, M. and UBS (2004) European Emissions Trading Scheme in The Materiality of Social, Environmental and Governance Issues to Equity Pricing, 41-46, Geneva: UNEP

Global Reporting Initiative, (2000) Sustainability Reporting Guidelines on Economic, Environmental, and Social Performance, June 2000, 54 pp.

Global Reporting Initiative (GRI) (2002) Sustainability Reporting Guidelines, Amsterdam: GRI.

www.globalreporting.org

Grandmont, R., Grant, G., Silva, F and Deutsche Bank (2004) Beyond the Numbers Corporate Governance: Implication for Investors in The Materiality of Social, Environmental and Governance Issues to Equity Pricing, 17-18, Geneva: UNEP.

Gregory, H. and Pollack, J.G. (2002) Corporate Social Responsibility, Global Counsel, March, 41-55 (www.practicallaw.com/global)

Group of 100 Incorporated (G100) (2003) Sustainability: A Guide to Triple

Bottom Line Reporting, www.group100.com.au

Guerard, J.B., (1997) Is there a Cost to Being Socially Responsible in Investing? Journal of Investing, Summer 1997

Hale, K. (2003) Corporate Law and Stakeholders: Moving Beyond Stakeholder Statutes, Arizona Law Review, 45: 823

Hamilton, S., Jo, H., and Statman, M., (1993) Doing Well While Doing Good? The Investment Performance of Socially Responsible Mutual Funds, Financial Analysts Journal, Nov-Dec

Hancock, E. (2005) Corporate Risk of Liability for Global Climate Change and the SEC Disclosure Dilemma, Georgetown International Environmental Law Review, 233: 249 
Horrigan, B. (2002) Fault Lines in the Intersection between Corporate Governance and Social Responsibility, University of New South Wales Law Journal, 25: 515

Husted, B. W. and Allen, D. B. (2000) Is It Ethical to Use Ethics as Strategy? Journal of Business Ethics, 27: (1-2) 21-31

Hutton, W. (2001) Putting Back the P in Plc: Public Companies and a New Corporate Citizenship, London: The Industrial Society

Institute for Sustainable Futures (2005) Mainstreaming SRI: A Role for Government, Institute for Sustainable Futures, University of Technology, Sydney

Institute of Chartered Accountants in Australia (ICAA) (2003) Environmental Management Accounting, Melbourne: ICAA

IUCN, UNEP \& WWF. 1991. Caring for the Earth. A Strategy for Sustainable Living. Gland, Switzerland. 228pp.

Jackson, D.F. (2004) Report of the Special Commission of Inquiry Into the Medical Research and Compensation Foundation, New South Wales Government

Jones, T. M. (1995). Instrumental stakeholder theory: A synthesis of ethics and economics. Academy of Management Review, 20(2): 404-437

Kennedy School of Government Corporate Responsibility Initiative (2004) Leadership, Accountability and Partnership: Critical Trends and Issues in Corporate Social Responsibility, Report of Launch Event 4 March 2004, Harvard University

Klein, E. and Du Plessis, J. (2005) Corporate Donations, the Best Interest of the Company and the Proper Purpose Doctrine, University of NSW Law Journal, 28: 69

KPMG (2005) International Survey of Corporate Responsibility Reporting, June, KPMG www.kpmg.com

KPMG (2005) The State of Sustainability Reporting in Australia, Sydney: KPMG, CAER and Deni Green Consulting Services

Kreander, N., Gray,R., Power,D., and Sinclair,C., (2000) Evaluating the Performance of Ethical and Non-Ethical Funds: A Matched Pair Analysis, University of Glasgow, Working Paper, July

Kurtz, L., (1997) The Impact of Social Screening on Growth-Oriented Investment Strategies, The Journal of Performance Measurement, Spring 
Kurtz, L. (1997) No Effect, or No Net Effects? Studies on Socially Responsible Investing', Journal of Investing, Winter: 37-49

Kytle, B. and Ruggie, J. (2005) Corporate Social Responsibility as Risk Management: A Model for Multinationals, Boston: Kennedy School of Government

Luis, C.( 2005), People v. Profits: A False Dichotomy? University of California Davis, Business Law Journal, 5,6

Mathieu, E., (2000) Response of UK Pension Funds to the SRI Disclosure Regulation, UK Social Investment Forum, October, 50 pp.

Mays (2003) Corporate Sustainability - An Investor Perspective, Department of Environment and Heritage, Commonwealth of Australia

McConvill, J. and Joy, M. (2003) The Interaction of Directors' Duties and Sustainable Development in Australia: Setting Off on the Uncharted Road, Melbourne University Law Review, 27: 116.

McKague, K. and Cragg, W. (2005) Compendium of Ethics Codes and Instruments of Corporate Responsibility, September

Minerals Council of Australia (2004) Enduring Value: The Australian minerals Industry Framework for Sustainable Development, MCA

Mitchel, L.A. (2001) Corporate Irresponsibility: America's Newest Export, Yale University Press

Monks, R., Miller, A. and Cook, J. (2004) Shareholder Activism on Environmental Issues: A Study of Proposals at Large US Corporations 2000-2003, Natural Resources Forum, 28: 317-330

Najam,A. (2000) World Business Council for Sustainable Development: The Greening of Business or a Greenwash?, Yearbook of International Cooperation on Environment and Development 1999/2000

OECD (1976, 2000) Guidelines for Multinational Enterprises, Paris: OECD

OECD, (1999) OECD Principles of Corporate Governance, Paris OECD, 48 pp.

OECD, (2001) Corporate Responsibility: Private Initiatives and Public Goals, Paris OECD, 112 pp.

OECD (2004) Principles of Corporate Governance, Paris: OECD 
OECD Watch (2005) Five Years On: A Review of the OECD Guidelines and National Contact Points, Amsterdam: Centre for Research on Multinational Corporations

Parkinson, J. (1994) Corporate Power and Responsibility: Issues in the Theory of Company Law, Oxford: Clarendon Press

Pleon (2005) Accounting for Good: The Global Stakeholder Report, Germany

PriceWaterhouseCoopers (PwC) (2001) The Role of Australia's Financial Sector in Sustainability, Report Prepared for Environment Australia

Redmond, P. (2005) Submission Parliamentary Joint Committee on Corporations and Financial Services Inquiry into Corporate Responsibility, Canberra: Commonwealth of Australia

Report of the Special Commission of Inquiry into the Medical Research and Compensation Foundation (Jackson Report) (2004) NSW

Russo, M.V. and Fouts, P.A. (1997) A Resource-Based Perspective on Corporate Environmental Performance and Profitability, Academy of Management Journal, June

Sauer, D.A., (1997) The Impact of Social-Responsibility Screens on Investment Performance: Evidence from the Domini 400 Social Index and Domini Equity Mutual Fund, Review of Financial Economics, Vol 6, No 2

Schroder, M. (2003) Socially Responsible Investments in Germany, Switzerland and the United States: An Analysis of Investment Funds and Indices, Mannheim: Centre for European Economic Research

Sethi, S.P. (2003) Setting Global Standards, Guidelines for Creating Codes of Conduct in Multinational Corporations, London: John Wiley \& Sons

Smith, N.C. (1990). Morality and the Market: Consumer pressure for corporate accountability. London: Routledge

Social Investment Forum, (1997) Report on Responsible Investing Trends in the United States, Washington, DC: Social Investment Forum Research Program

Social Investment Forum Industry (2001) 2001 Report on Socially Responsible Investing Trends in the United States, Washington D.C.: Social Investment Forum Research Program

Solomon, J. F., Solomon, A. and Norton, S. D. (2002) Socially Responsible Investing in the UK: Drivers and Current Issues, Journal of General Management, 27: (3) 1-13 
Sparkes, R. and Cowton, C.J. (2004) The Maturing of Socially Responsible Investment: A Review of the Developing Link with Corporate Social Responsibility, Journal of Business Ethics, 52 (1): 45-57

Sparkes,R. (2002) Socially Responsible Investment; A Global Revolution, London: Wiley Europe

Statman, M., (2000) Socially Responsible Mutual Funds, Financial Analysts Journal, May-June

SustainAbility, (2001) Buried Treasure - Uncovering the Business Case for Corporate Sustainability, UNEP/SustainAbility

SustainAbility Ltd / UNEP (2002) Trust Us - The Global Reporters 2002 Survey of Corporate Sustainability Reporting, SustainAbility Ltd / UNEP www.sustainability.com

SustainAbility (2005) The Changing Landscape of Liability: A Director's Guide to Trends in Corporate Environmental, Social and Economic Liability, London: SustainAbility

Teck Corp Ltd v Millar (1973) Delaware Law Review 33, (3d)

UBS Warburg (2001) Sustainability Investment, UBS Warburg, August

UK Department of Trade and Industry (2001) Business and Society: Developing Corporate Social Responsibility in the UK, London: DTI, March 18 pp.

UK Social Investment Forum (2001) www.uksif.org/home/welcome/content.shtml

UK Department for Environment, Food and Rural Affairs (2005) Environmental Key Performance Indicators: Reporting Guidelines for UK Business, London: UK DEFRA.

UN (1992) Rio Declaration on Environment and Development, Geneva: UN

UN (2000) Global Compact, Geneva: UN

UNCTAD (2004) Development and Globalisation: Facts and Figures, Geneva: UN

UNEP Finance Initiative (2002) Climate Change and the Financial Services Industry, Geneva: UNEP.

UNEP Finance Initiative (2002) Financing for Sustainable Development, Geneva: UNEP, UNEP Finance Initiative (2002) Financing Sustainable Energy Directory: A Listing of Lenders and Investors, Geneva: UNEP 
UNEP Finance Initiative (2002) Foreign Direct Investment: Financing Sustainability, Geneva: UNEP

UNEP Finance Initiative (2002) Industry as a Partner for Sustainable Development: finance and Insurance, Geneva: UNEP

UNEP Finance Initiative (2002) Sustainable Venture Finance, Geneva: UNEP

UNEP Finance Initiative (2003) Environmental Disclosure in Financial Statements, Geneva: UNEP

UNEP Finance Initiative (2003) Mainstreaming Sustainable Investment Geneva: UNEP

UNEP Finance Initiative (2003) Risk, the Environment, and the Role of the Insurance Industry, Geneva: UNEP

UNEP Finance Initiative (2004) Generation Lost: Young Financial Analysts and Environmental, Social and Governance Issues, Geneva: UNEP.

UNEP Finance Initiative (2004) Implementing Responsible Investment, Geneva: UNEP

UNEP Finance Initiative (2004a) The Materiality of Social, Environmental and Governance Issues to Equity Pricing, Geneva: UNEP.

UNEP Finance Initiative (2004) Values to Value: A Global Dialogue on Sustainable Finance, Geneva: UNEP.

UNEP Finance Initiative (2005) CEO Briefing on the Future of Climate Change Policy: The Financial Sector Perspective, Geneva: UNEP

UNEP Finance Initiative (2005) A Legal Framework for the Integration of Environmental, Social and Governance Issues into Institutional Investment, October, Geneva: UNEP

United States Environmental Protection Agency (EPA), (1995) An Introduction to Environmental Accounting as a Business Management Tool: Key Concepts and Terms, Washington, DC: EPA

United States Environmental Protection Agency (EPA), (2000), The Lean and Green Supply Chain: A Practical Guide for Materials and Supply Chain Managers to Reduce Costs and Improve Financial Performance, Washington, DC: EPA

U.S. Environmental Protection Agency (US EPA) (2000) Green Dividends? The Relationship between Firms' Environmental Performance and Financial Performance www.epa.gov/ocempage 
Vogel, D. (2005) The Market for Virtue: The Potential and Limits of Corporate Social Responsibility, Washington DC: Brookings Institute

Waddock, S. (2003) Myths and realities of social investing. Organization \& Environment, 16(3): 369-380

Waddock, S. (2004) Creating Corporate Accountability: Foundation Principles to Make Corporate Citizenship Real, Journal of Business Ethics, 50: 1-15

Waddock, S.A. and Graves, S. B. (1997) The corporate social performance-financial performance link, Strategic Management Journal, 18(4): 303-319

Wedderburn (1985) Southey Memorial Lecture 1984: The Social Responsibility of Companies, Melbourne University Law Review, 15: 4

Welford, R. (2002) Globalisation, Corporate Social Responsibility and Human Rights, Corporate Social Responsibility and Environmental Management, 9 (1): 1-7

Wells, H. (2002) The Cycles of Corporate Social Responsibility: An Historical Retrospective for the Twenty-First Century, Kansas Law Review 51: 77

Williams, C. (2002) Symposium: Corporations Theory and Corporate Governance Law. Corporate Social Responsibility in an Era of Economic Globalisation, University of California Davis Law Review, 35: 705

World Bank Group (2002 Public Sector Roles in Strengthening Corporate Social Responsibility: A Baseline Study, Washington DC: WBG

World Bank Group (2003) Strengthening Implementation of Corporate Social Responsibility in Global Supply Chains, October, Washington DC: WBG

World Bank Group (2004) Public Sector Roles in Strengthening Corporate Social Responsibility: Taking Stock, Washington DC: WBG

World Business Council for Sustainable Development (WBCSD) (2002) Corporate Social Responsibility: The WBCSD's Journey. WBCSD

World Business Council for Sustainable Development (2004) Running the Risk WBCSD

World Business Council for Sustainable Development (2005) Beyond Reporting:

Creating Business Value And Accountability, WBCSD

World Economic Forum (2005) Mainstreaming Responsible Investment, World Economic Forum 
World Resources Institute, United Nations Environment Programme, and the World Business Council for Sustainable Development, Tomorrow's Markets - Global Trends and Their Implications for Business (2002) Washington, DC: World Resources Institute, United Nations Environment Programme, and the World Business Council for Sustainable Development

Zadek, S. (2004) The Path to Corporate Responsibility, Harvard Business Review, December, Boston: HBR

\section{THOMAS CLARKE}

Professor of Management and Director of the UTS Research Centre for Corporate Governance, Sydney Australia. His research includes the changing roles of company boards and directors, and comparative corporate governance. He is interested in the critique of shareholder value and the relationship of governance to strategy and innovation. Recent publications include Theories of Corporate Governance, London: Routledge, 2004; Corporate Governance: Critical Perspectives, London: Routledge, 2005; Corporate Governance and Globalisation, London: Sage, 2006 (with Marie dela Rama); International Corporate Governance, London: Routledge, 2007; Fundamentals of Corporate Governance, London: Sage 2008, (with Marie dela Rama); and European Corporate Governance, London: Routledge 2009 (with Jean-Francois Chanlat).

\section{ALICE KLETTNER}

Alice Klettner is a Research Associate in the UTS Centre for Corporate Governance, working on corporate social responsibility and regulation. She is a solicitor registered in England and New South Wales, Australia. She was awarded a first class honours degree in biochemistry at Cambridge University, and a Masters in International Law at the University of Sydney. 